\title{
PENGARUH PENGAPURAN DAN PEMUPUKAN FOSFOR PADA TANAH YANG SERING TERGENANG TERHADAP PERTUMBUHAN DAN HASIL KACANG TANAH (Arachis hypogaea L.)
}

\author{
Bukhari $^{(1)}$, Nuryulsen Safridar ${ }^{(2)}$, Rudi Fadli ${ }^{(3)}$ \\ Program Studi Agroteknologi Fakultas Pertanian Universitas Jabal Ghafur-Aceh \\ Email : bukhari@unigha.ac.id
}

The purpose of this study were: (1) To determine the effect of dolomite lime and phosphorus fertilization on soils that were often inundated on the growth and yield of peanuts, (2) to determine the interaction between these two factors on the growth and production of peanuts in soils that were often inundated. . The experimental design used in this study was "Randomized Block Design", with 3 (three) replications and 2 (two) factors studied, namely the effect of dolomite (Liming) (K) lime with 4 (four) levels, namely; K0 $=0 \mathrm{gr} /$ polybag, $\mathrm{K} 1$ $=2 \mathrm{gr} /$ polybag, $\mathrm{K} 2=4 \mathrm{gr} /$ polybag, and K3 = $6 \mathrm{gr} /$ polybag. While Phosphorus $(\mathrm{Sp}-36)(\mathrm{P})$ fertilization with 3 (three) levels, namely; $\mathrm{P} 0=0 \mathrm{gr} /$ polybag, $\mathrm{P} 1=2.5 \mathrm{gr} /$ polybag, $\mathrm{P} 2=5 \mathrm{gr}$ / polybag. The variables observed to show the effect of dolomite lime and Sp-36 fertilization were: (1) Plant height: measured at the age of 21, 42, 63 days after planting (DAS). (2) Number of branches per clump (cm). (3) The number of flowers per family. (4) The yield of pods per poly bag (gram). And (5) the number of pods per (fruit). The results of the research on the effect of dolomite liming treatment on the growth and yield of groundnut showed that: (1) had a very significant effect (level of 1\%) on plant height at 21, 42 and 63 DAS, (2) had no significant effect on the number of branches per clump, (2) 3) It had a significant effect (level of 5\%) on the number of flowers per clump, (4) had a very significant effect (level of $1 \%$ ) on the yield of pods per polybag, and (5) had a very significant effect (level of 1\%) on the number of pods per hill. While the effect of phosphorus fertilization treatment on the growth and yield of peanuts showed that: (1) had a very significant effect (level of 1\%) on plant height at 21 and 42 DAS, (2) had no significant effect on the number of branches per clump, (3) very real (level 1\%) on the number of flowers per clump, (4) had a very significant effect (level 1\%) on the yield of pods per polybag, and (5) had a significant effect (level 5\%) on the number of pods per hill. The interaction between dolomite liming and phosphorus fertilization on the growth and yield of peanuts in all the variables studied (plant height, number of branches per clump, number of flowers per clump, yield of pods per polybag and number of pods per hill), showed a very significant effect (level 1\%).

Keywords : Dolomitte lim e, phosphorus fertilization, soil, peanuts.

\section{Pendahuluan}

Kacang tanah (Arachis hypogaea L.) merupakan tanaman polongan atau legum kedua terpenting setelah kedelai di Indonesia. Tanaman ini berasal dari benua Amerika tepatnya dari daerah Brazilia (Amerika Latin), namun saat ini telah menyebar ke seluruh dunia yang beriklim tropis atau subtropis. Republik Rakyat Cina dan India merupakan penghasil kacang tanah terbesar dunia. Sebagai tanaman budidaya, kacang tanah terutama dipanen bijinya yang kaya protein dan lemak. Biji ini dapat dimakan mentah, direbus (di dalam polongnya), digoreng, atau disangrai. Selain dipanen biji atau polongnya, kacang tanah juga dapat dipanen hijaunya (daun 
dan batang) untuk makanan ternak atau merupakan pupuk hijau (Hasyim, 2005).

Masyarakat Indonesia mengenal kacang tanah sebagai bahan pangan dan industri, di samping dapat menunjang kehidupan manusia dan hewan, juga dapat bermanfaat untuk memperbaiki tanah dan menambah unsur hara tanah. Kacang tanah dapat meningkatkan kesuburan tanah karena pada akar tanaman ini terdapat bakteri Rhizobium yang dapat memfiksasi $\mathrm{N}$ dari udara (Sumarno, 1986). Biji kacang tanah mengandung $20-30 \%$ protein, $40-$ $50 \%$ lemak, $11,6 \%$ karbohidrat, 2,8 \% serat kasar, $0,6 \% \mathrm{Ca}, 0,38 \%$ fosfor dan $5 \%$

Kacang tanah dapat diolah menjadi berbagai macam bahan makanan dan dapat di konsumsi dalam berbagai bentuk, antara lain sebagai bahan sayur, saus dan digoreng atau direbus, Disamping itu kacang tanah dapat dibuat keju, mentega, sabun dan minyak. Daun kacang tanah dapat digunakan sebagai pakan ternak dan pupuk. Hasil sampingan dari pembuatan minyak berupa bungkil dapat dijadikan oncom dengan bantuan fermentasi jamur.

Saat ini produksi kacang tanah masih sangat rendah yaitu antara $\quad 0,7$ - 1,5 ton polong kering per hektar. Produksi yang sangat rendah ini disebabkan oleh beberapa faktor antara lain teknik budidaya yang masih belum sempurna. Mengingat masih terbatasnya kemampuan untuk memenuhi kebutuhan kacang tanah di dalam negeri yang semakin meningkat, maka usaha untuk meningkatkan hasil seyogyanya mendapat perhatian utama, usaha tersebut diantaranya dapat di tempuh dengan cara :

1.Pengolahan tanah yang baik dan optimal

2.Penggunaan varietas unggul

3.Jarak tanam

4.Pemupukan yang seimbang

5.Perbaikan tanaman

6.Pemeliharaan tanaman

7.Pengendalian hama dan penyakit

8.Dan lain-lain (Anonymous, 2002). air, yang memiliki potensi untuk dikembangkan secara luas sebagai bahan baku agroindustri. Disamping itu kacang tanah juga mengandung mineral-mineral seperti Ca, P, Fe serta vitamin A, B, C, D, E dan K. Dalam bentuk kalori 100 gram biji kacang tanah menghasilkan 540 kalori tertinggi dari tanaman lain. Senyawasenyawa ini sangat dibutuhkan oleh organ tubuh manusia sebagai sumber energi (Suprapto, 2000).

Pada tanah yang sering tergenang dapat menyebabkan kesuburan tanah berkurang dan $\mathrm{pH}$ rendah serta kurang tersedianya unsur hara terutama fosfat. Pengapuran dan pemupukan fosfor merupakan salah satu usaha yang harus ditempuh untuk memperbaiki sifat-sifat tanah yang tergenang tersebut. Pada tanah yang asam atau $\mathrm{pH}$-nya rendah efisiensi bakteri dalam mengikat $\mathrm{N}$ dari udara akan sangat berkurang, sehingga pengaruh pemberian kapur dolomit dan pupuk fosfor terhadap pertumbuhan dan hasil kacang tanah perlu diteliti.

\section{Tujuan Penelitian}

Penelitian ini bertujuan :

1. Untuk mengetahui pengaruh pemberian kapur dan pemupukan fosfor pada tanah yang sering tergenang terhadap pertumbuhan dan hasil kacang tanah.

2. Untuk mengetahui pengaruh interaksi antara kedua faktor tersebut terhadap pertumbuhan dan produksi kacang tanah pada tanah yang sering tergenang

\section{Hipotesis}

a. Pemberian kapur berpengaruh terhadap pertumbuhan dan hasil kacang tanah pada tanah yang sering tergenang. 
JAR,Volume 3 Nomor 2 Agustus 2020 $p$-ISSN 2615-417X, $e$-ISSN 2721-0782

b. Pemberian pupuk fosfor pada tanah yang sering tergenang berpengaruh terhadap pertumbuhan dan hasil kacang tanah.

c. Ada interaksi kedua faktor tersebut terhadap pertumbuhan dan hasil kacang tanah pada tanah yang sering tergenang.

\section{HASIL DAN PEMBAHASAN}

\section{A. Pengaruh Pemberian Kapur Dolomit Terhadap Pertumbuhan dan Hasil Kacang Tanah}

1. Tinggi Tanaman Umur 21, 42, 63 HST

Hasil pengamatan terhadap Pengapuran dolomit pada umur 21, 42 dan 63 HST dapat dilihat pada lampiran 1, 3 dan 5. Hasil sidik ragam menunjukkan bahwa ; pengaruh Pengapuran dolomit pada tanaman kacang tanah berpengaruh sangat nyata terhadap tinggi tanaman pada umur 21 , 42 dan 63.

Rata - rata tinggi tanaman kacang tanah akibat Pengapuran pada umur 21, 42 dan 63 HST dapat dilihat pada

Tabel

Tabel 1. Rata - rata Tinggi Tanaman Kacang Tanah Umur 21, 42 dan 63 HST Akibat Pemberian Kapur

\begin{tabular}{|c|c|c|c|}
\hline \multirow{2}{*}{ Perlakuan } & \multicolumn{3}{|c|}{ Tinggi Tanaman Umum (cm) } \\
\cline { 2 - 4 } & 2 HST & 42 HST & 63 HST \\
\hline $\mathrm{K} 0=0 \mathrm{~g} /$ Rumpun & $11,00 \mathrm{a}$ & $29,17 \mathrm{a}$ & $38,78 \mathrm{a}$ \\
\hline $\mathrm{K} 1=2 \mathrm{~g} /$ Rumpun & $11,78 \mathrm{~b}$ & $29,78 \mathrm{~b}$ & $40,00 \mathrm{ab}$ \\
\hline $\mathrm{K} 2=4 \mathrm{~g} /$ Rumpun & $11,78 \mathrm{~b}$ & $30,22 \mathrm{bc}$ & $40,33 \mathrm{ab}$ \\
\hline $\mathrm{K} 3=6 \mathrm{~g} /$ Rumpun & $11,67 \mathrm{~b}$ & $30,83 \mathrm{~d}$ & $40,67 \mathrm{~b}$ \\
\hline $\mathrm{BNJ}=0,05$ & 0,34 & 0,57 & 1,83 \\
\hline
\end{tabular}

Keterangan: Angka yang diikuti oleh huruf yang sama, pada lajur yang sama tidak berbeda nyata pada taraf $5 \%$ (Uji BNJ 0.05 )

Dari Tabel 1, terlihat bahwa ada perbedaan tinggi tanaman kacang tanah pada umur 21, 42 dan 63 HST yang diberikan kapur, rata-rata tinggi tanaman yang diberikan kapur terlihat lebih baik dibandingkan dengan tanaman yang tidak diberikan kapur,m semakin tinggi diberikan kapur pada tanah tergenang dapat memperlihatkan pertumbuhan tinggi kacang tanah yang lebih baik, sehingga kapur mutlak diperlukan pada tanah tergenang untuk memperbaiki pertumbuhan tanaman.
2. Jumlah Cabang per rumpun

Hasil zidik ragam menunjukkan bahwa; pengapuran brpengaruh tidak nyata terhadap jumlah cabang (uji $\mathrm{F}: \mathrm{F}_{\text {hitung }}<\mathrm{F}_{\text {tabel }}$ ). Hal ini menunjukkan bahwa jumlah cabang tidak dipengaruhi oleh pemberian kapur. Hal ini diduga bahwa jumlah cabang tanaman kacang tanah merupakan sifat genetik yang diwariskan oleh induk suatu tanaman

3. Jumlah Bunga per rumpun 
JAR,Volume 3 Nomor 2 Agustus 2020 $p$-ISSN 2615-417X, $e$-ISSN 2721-0782

Hasil sidik ragam menunjukkan bahwa pengapuran berpengaruh nyata terhadap jumlah bunga per rumpun pada taraf $0.05 \%$ (uji F : $F_{\text {hitung }}>\mathrm{F}_{\text {tabel }}$ ).

Rata - rata jumlah bunga per rumpun tanaman kacang tanah akibat Pengapuran dapat dilihat pada Tabel 2. Berikut

Tabel 2. Rata - rata Jumlah Bunga per rumpun Tanaman Kacang Tanah akibat Pemberian Kapur

\begin{tabular}{|c|c|}
\hline $\begin{array}{c}\text { Perlakuan } \\
\text { Pengapuran }\end{array}$ & Jumlah Bunga/Rumpun \\
\hline $\mathrm{K} 0=0 \mathrm{~g} /$ Rumpun & $4,11 \mathrm{a}$ \\
\hline $\mathrm{K} 1=2 \mathrm{~g} /$ Rumpun & $4,56 \mathrm{~b}$ \\
\hline $\mathrm{K} 2=4 \mathrm{~g} /$ Rumpun & $4,56 \mathrm{~b}$ \\
\hline $\mathrm{K} 3=6 \mathrm{~g} /$ Rumpun & $4,67 \mathrm{~b}$ \\
\hline $\mathrm{BNJ}=0,05$ & 0,37 \\
\hline
\end{tabular}

Keterangan: Angka yang diikuti oleh huruf yang sama, tidak berbeda nyata pada taraf $5 \%$ (Uji BNJ 0.05 )

Berdasarkan Tabel 2, dapat dilihat bahwa ada perbedaan jumlah bunga per rumpun kacang tanah, pengaruh perlakuan pemberian kapur terbaik dijumpai pada nilai rerata Pengapuran dolomit $\mathrm{K}_{3}$. Yang memberikan indikasi bahwa tanah tergenang menghendaki pemberian sangat nyata terhadap jumlah polong kacang tanah per rumpun pada taraf $0.01 \%$ (uji F : $\mathrm{F}_{\text {hitung }}>\mathrm{F}_{\text {tabel }}$ ). kapur untuk meningkatkan $\mathrm{pH}$ tanah. Peningkatan $\mathrm{pH}$ dapat menetralisasi pengaruh keracunan Al, Fe dan Mn.

4. Jumlah Polong per rumpun

Hasil sidik ragam menunjukkan bahwa pengapuran berpengaruh

Rata - rata jumlah polong per rumpun tanaman kacang tanah akibat pengapuran dolomit dapat dilihat pada Tabel 3.

Tabel 3. Rata - rata Jumlah Polong per rumpun Tanaman Kacang Tanah akibat pengapuran.

\begin{tabular}{|c|c|}
\hline $\begin{array}{c}\text { Perlakuan } \\
\text { Pengapuran }\end{array}$ & Jumlah Polong/Rumpun \\
\hline $\mathrm{K} 0=0 \mathrm{~g} /$ Rumpun & $17,00 \mathrm{a}$ \\
\hline $\mathrm{K} 1=2 \mathrm{~g} /$ Rumpun & $18,44 \mathrm{~b}$ \\
\hline $\mathrm{K} 2=4 \mathrm{~g} /$ Rumpun & $20,11 \mathrm{c}$ \\
\hline $\mathrm{K} 3=6 \mathrm{~g} /$ Rumpun & $20,22 \mathrm{c}$ \\
\hline $\mathrm{BNJ}=0,05$ & 1,13 \\
\hline
\end{tabular}

Keterangan : Angka yang diikuti oleh huruf yang sama, tidak berbeda nyata pada taraf $5 \%$ (Uji BN] 0.05 ) 
Dari Tabel 3 dapat dilihat bahwa ada perbedaan jumlah polong kacang tanah per rumpun yang diberikan kapur, Perlakuan yang terbaik dijumpai pada nilai rerata pengapuran dolomit $\mathrm{K}_{3}$ walau secara statistika tidak berbeda dengan $\mathrm{K}_{2}$.

5. Hasil Polong per rumpun
Hasil sidik ragam menunjukkan bahwa pengapuran berpengaruh sangat nyata terhadap hasil polong kacang tanah per rumpun pada taraf $0.01 \%$ (uji F : $F_{\text {hitung }}>F_{\text {tabel }}$ ).

Rata - rata hasil polong per rumpun tanaman kacang tanah akibat pengapuran dapat dilihat pada Tabel 4 .

Tabel 4. Rata - rata hasil Polong per rumpun Tanaman Kacang Tanah akibat pengapuran.

\begin{tabular}{|c|c|}
\hline $\begin{array}{c}\text { Perlakuan } \\
\text { Pengapuran }\end{array}$ & Berat Polong/Rumpun \\
\hline $\mathrm{K} 0=0 \mathrm{~g} /$ Rumpun & $26,78 \mathrm{a}$ \\
\hline $\mathrm{K} 1=2 \mathrm{~g} /$ Rumpun & $28,56 \mathrm{~b}$ \\
\hline $\mathrm{K} 2=4 \mathrm{~g} /$ Rumpun & $28,72 \mathrm{~b}$ \\
\hline $\mathrm{K} 3=6 \mathrm{~g} /$ Rumpun & $29,33 \mathrm{~b}$ \\
\hline $\mathrm{BNJ}=0,05$ & 1,62 \\
\hline
\end{tabular}

Keterangan : Angka yang diikuti oleh huruf yang sama, tidak berbeda nyata pada taraf $5 \%$ (Uji BNJ 0.05 )

Berdasarkan Tabel 4, dapat dilihat bahwa ada perbedaan hasil polong per plot kacang tanah akibat pemberian kapur. Hasil polong terbaik diperoleh pafda $\mathrm{K}_{3}$, Walaupun secara statistika tidak berbeda dengan $\mathrm{K}_{1}$ dan $\mathrm{K}_{2}$, tetapi berbeda dengan $\mathrm{K}_{0}$.

Pemberian kapu berpengaruh terhadap sebagian besar parameter yang diamati, ini diduga kapur $b$ erperan untuk menaikkan $\mathrm{pH}$ pada tanah-tanah ber $\mathrm{pH}$ rendah termasuk tanah tergenang sehingga keracunan $\mathrm{Al}, \mathrm{Fe}$ dan $\mathrm{Mn}$ dapat dinetralkan.

Hakim dkk, (1986) menyataakan bahwa pemberian kapur juga dapat berpengaruh terhadap biologi tanah, perngaruh langsung terhadap biologi tanah adalah tersedianya unsur hara yang dibutuhkan jasad renik tanah yang
Menurut Hardjowigeno (2003) pemberian kapur umumnya bukan ditujukan untuk menambah $\mathrm{Ca}$ ke dalam tanah, akan tetapi untuk menaikkan $\mathrm{pH}$ tanah yang terlalu asamn. Mallarino (1995) menyatakan pemberian kapur dolomit di samping dapat menaikkan $\mathrm{pH}$ juga berguna untuk menambahkan $\mathrm{Ca}$ dan $\mathrm{Mg}$, meningkatkan ketersediaan $\mathrm{P}$ dan Mo, mengurang keracunan $\mathrm{Al}$, Fe dan Menserta pemberian kapur dapat memperbaiki kehidupan jasad renik dan juga dapat mendorong pembentukan bintil akar.

menyebabkan jasad renik tersebut mudah memperoleh energy dan materi sehingga aktifitasnyapun meningkat. Semua ini berdampak posisitif terhadap pertumbuhan dan hasil kacang tanah yang ditanam pada tanah tergenang. 
B. Pengaruh Pemberian Pupuk Fosfor Terhadap Pertumbuhan dan Hasil Kacang Tanah

1. Tinggi Tanaman

Hasil sidik ragam menunjukkan bahwa pemupukan fosfor
JAR, Volume 3 Nomor 2 Agustus 2020 $p$-ISSN 2615-417X, $e$-ISSN 2721-0782

berpengaruh sangat nyata terhadap tinggi tanaman pada 21 dan 42 HST pada taraf $0.01 \%$ (uji $\mathrm{F}: \mathrm{F}_{\text {hitung }}>\mathrm{F}_{\text {tabel }}$ ). Rata - rata tinggi tanaman kacang tanah umur 21 dan 42 HST akibat pemupukan fosfor dapat dilihat pada Tabel 5.

Tabel 5.Rata - rata Tinggi Tanaman Umur 21 dan 42 HST akibat pemupukan Fosfor

\begin{tabular}{|c|c|c|}
\hline \multirow{2}{*}{ Perlakuan } & \multicolumn{2}{|c|}{ Tinggi Tanaman Umur (cm) } \\
\cline { 2 - 3 } & 21 HST & 42 HST \\
\hline $\mathrm{P} 0=0 \mathrm{~g} /$ Rumpun & $11,42 \mathrm{~b}$ & $29,67 \mathrm{a}$ \\
\hline $\mathrm{P} 1=2,5 \mathrm{~g} /$ Rumpun & $11,75 \mathrm{~b}$ & $29,67 \mathrm{a}$ \\
\hline $\mathrm{P} 2=5 \mathrm{~g} /$ Rumpun & $11,50 \mathrm{~b}$ & $30,67 \mathrm{~b}$ \\
\hline $\mathrm{BNJ}=0,05$ & 0,30 & 0,49 \\
\hline
\end{tabular}

Keterangan : Angka yang diikuti oleh huruf yang sama, pada lajur yang sama pada taraf $5 \%$ (Uji BNJ 0.05 )

Berdasarkan Tabel 5 dapat dilihat bahwa ada perbedaan tinggi taanaman kacang tanah pada umur 21 dan 42 HST. Pengaruh perlakuan yang terbaik dijumpai pada nilai rerata pemupukan fosfor $\mathrm{P}_{2}$ ( $5 \mathrm{~g}$ / rumpun).

2. Jumlah Cabang per rumpun

Hasil sidik ragam menunjukkan pemupukan fosfor tidak berpengaruh nyata terhadap jumlah cabang (uji F : $F_{\text {hitung }}<\mathrm{F}_{\text {tabel }}$ ).

Tabel 6.Rata - rata Jumlah Bunga per rumpun Tanaman Kacang Tanah akibat Pemupukan Fosfor

\begin{tabular}{|c|c|}
\hline Perlakuan & Jumlah Bunga Per Rumpun \\
\hline $\mathrm{P} 0=0 \mathrm{~g} /$ Rumpun & $4,42 \mathrm{a}$ \\
\hline $\mathrm{P} 1=2,5 \mathrm{~g} /$ Rumpun & $4,58 \mathrm{~b}$ \\
\hline $\mathrm{P} 2=5 \mathrm{~g} /$ Rumpun & $5,17 \mathrm{~b}$ \\
\hline $\mathrm{BNJ}=0,05$ & 0,64 \\
\hline
\end{tabular}

Keterangan: Angka yang diikuti oleh huruf yang sama, pada jalur yang sama tidak berbeda nyata pada taraf $5 \%$ (Uji BNJ 0.05 )
3. Jumlah Bunga per rumpun

Hasil sidik ragam menunjukkan bahwa pemupukan fosfor pada tanaman kacang tanah berpengaruh sangat nyata terhadap jumlah bunga per rumpun pada taraf $0.01 \%$ (uji F : $F_{\text {hitung }}>F_{\text {tabel }}$ ).

Rata- rata jumlah bunga per rumpun tanaman kacang tanah akibat pemupukan fosfor dapat dilihat pada Tabel 6. 
Berdasarkan Tabel 6 dapat dilihat bahwa ada perbedaan jumlah bunga per rumpun pada tanaman kacang

4. Jumlah Polong per rumpun

Hasil sidik ragam menunjukkan bahwa pengaruh pemupukan fosfor pada tanaman kacang tanah berpengaruh nyata terhadap hasil tanah. Pengaruh perlakuan yang terbaik dijumpai pada nilai rerata pemupukan fosfor $\mathrm{P}_{2}$.

polong per rumpun pada taraf $0.05 \%$ (uji F : $F_{\text {hitung }}>F_{\text {tabel }}$ )'

Rata - rata jumlah polong per rumpun tanaman kacang tanah akibat pemupukan fosfor dapat dilihat pada Tabel 7.

Tabel 7.Rata - rata Jumlah Polong per rumpun Tanaman Kacang Tanah akibat pemupukan Fosfor.

\begin{tabular}{|c|c|}
\hline Perlakuan & Jumlah polong Per Rumpun \\
\hline $\mathrm{P} 0=0 \mathrm{~g} /$ Rumpun & $18,58 \mathrm{a}$ \\
\hline $\mathrm{P} 1=2,5 \mathrm{~g} /$ Rumpun & $18,83 \mathrm{~b}$ \\
\hline $\mathrm{P} 2=5 \mathrm{~g} /$ Rumpun & $19,42 \mathrm{~b}$ \\
\hline $\mathrm{BNJ}=0,05$ & 0,98 \\
\hline
\end{tabular}

Keterangan: Angka yang diikuti oleh huruf yang sama, tidak berbeda nyata pada taraf $5 \%$ (Uji BNJ 0.05 )

Berdasarkan label /, dapat dilınat bahwa ada perbedaan jumlan polong per rumpun pada tanaman kacang tanah. Pengaruh perlakuan yang terbaik dijumpai pada nilai rerata pemupukan fosfor $\mathrm{P}_{2}$.

5. Hasil Polong per rumpun

Hasil sidik ragam menunjukkan bahwa pemupukan fosfor pada tanaman kacang tanah berpengaruh sangat nyata terhadap pada hasil polong per rumpun pada taraf 0.01 $\%$ (uji F : $\left.\mathrm{F}_{\text {hitung }}>\mathrm{F}_{\text {tabel }}\right)$.

Rata - rata hasil polong per polybag tanaman kacang tanah akibat pemupukan fosfor dapat dilihat pada Tabel 8

Tabel 8. Rata - rata Hasil Polong per polybag Tanaman Kacang Tanah akibat Pemupukan Fosfor

\begin{tabular}{|c|c|}
\hline Perlakuan & Jumlah Bunga Per Rumpun \\
\hline $\mathrm{P} 0=0 \mathrm{~g} /$ Rumpun & $27,42 \mathrm{a}$ \\
\hline $\mathrm{P} 1=2,5 \mathrm{~g} /$ Rumpun & $28,67 \mathrm{~b}$ \\
\hline $\mathrm{P} 2=5 \mathrm{~g} /$ Rumpun & $28,96 \mathrm{~b}$ \\
\hline $\mathrm{BNJ}=0,05$ & 1,41 \\
\hline
\end{tabular}

Keterangan : $\quad$ Angka yang diikuti oleh huruf yang sama, tidak berbeda nyata pada taraf $5 \%$ (Uji BNJ 0.05) 
Berdasarkan Tabel 8 ada perbedaan hasil polong per rumpun tanaman kaacang tanah yang diberikan pupuk fosfor berbeda, perlakuan $\mathrm{P}_{2}(5 \mathrm{~g} /$ rumpun ) memperlihatkan hasil polong tertinggi, namun tidak berbeda dengan $\mathrm{P}_{1}$.

Dari hasil uji statistika ternyata bahwa pemupukan fosfor pada tanah tergenang berpengaruh terhadap

Salisbury dan Ross (1995) yaitu pada rentang konsentrasi yang rendah yang dinamakan dengan daerah kahat. Pertumbuhan naik dengan sangat tajam bila unsur yang kahat tersebut diberikan dan konsenterasinya lebih banyak di daalam tanaman, sedangkan peningkatan konsenterasi di daerah yang berkecukupan tidfak banyak pengaruhnya pada pertumbuhan dan hasil tanaman. Gardner, dkk., (1991) menyatakan bahwa pemupukan $\mathrm{P}$ mengakibatkan peningkatan pengambilan $\mathrm{P}$ dikarenakan adanya konsenterasi $\mathrm{P}$ yang lebih tinggi dalam medium atau atau karena perpanjangan akar atau ke dua-duanya. Fosfor secara aktif diserap oleh akar dari alarutan tanah dan disimpan di dalam tubuh tanaman dalam konsenterasi tinggi. Loveless, (1989) menyatakan bahwa fosforb berhubungan dengan mekanisme biokimia yang menyimpan energi dan kemudian memindahkannya ke dalam sel-sel yang hidup. Selanjutnya Gardner dkk., (1991) menambahkan fosfor merupalkan komponen structural dari sejumlah senyawa penting pentransfer energy ADP dan ATP ( Adenosin di- dan trifosfat), pertumbuhan dan hasil kacang tanah. Berpengaruhnya pemupukan fosfor tersebut dikarenakan tanah tergenang merupakan salah satu tanah yang mengandung $\mathrm{P}$ yang rendah, sehingga pemupukan fosfat pada tanah tersebut nyata meningkatkan ketersediaan $P$ tanah yang akhirnya dapat meningkatkan hasil kacang tanah. Keadaan ini sesuai dengan pernyataan

NAD dan NADH serta senyawa-senyawa system informasi genetic DNA dan RNA ( asam di dan kephalin yang berperan penting dalam haloksiribo dan ribonukleat), di samping itu juga fosfor merupakan bahan penyusun fosfolipid seperti lesitin dan kephalin yang berperan penting dalam hal integritas membrane. Peningkatan serapan fosfor pada tanaman menyebabkan laju fotosintesis meningkat (Mulyanis, 1997). Peningkatan fotosintesis akan mengakibatkan peningkatan akumulasi fotosintat untuk selanjutnya ditransfer ke seluruh bagian tanaman yang membutuhkannya dan digunakan sebagai energy dalam pertumbuhan tanaman (Barber, 1984). Pengaruh baik dari pemupukan fosfat dapat meningkatkan panjang dan bobot akar, meningkatkan hasil polong yang berarti meningkatkan hasl kacang tanah.

\section{Interaksi Antara Pengapuran Dolomit dan Pemupukan Fosfor Terhadap Pertumbuhan dan Hasil Kacang Tanah}


JAR, Volume 3 Nomor 2 Agustus 2020 $p$-ISSN 2615-417X, $e$-ISSN 2721-0782

Berdasarkan hasil sidik ragam (Lampiran 2, 4, 6, 8, 10, 12 dan 14), menunjukkan bahwa interaksi antara Pengapuran dolomit dan pemupukan fosfor :

(1) Berpengaruh sangat nyata (uji $F: F_{\text {hitung }}$ $>\mathrm{F}_{\text {tabel }}$ ) taraf $1 \%$ pada tinggi tanaman kacang tanah umur 21, 42 dan 63 HST.

(2) Berpengaruh sangat nyata (uji $F: F_{\text {hitung }}$ $>\mathrm{F}_{\text {tabel }}$ ) taraf $1 \%$ pada jumlah cabang per rumpun.

(3) Berpengaruh sangat nyata (uji $F$ : $F_{\text {hitung }}$ $\left.>\mathrm{F}_{\text {tabel }}\right)$ taraf $1 \%$ pada jumlah bunga per rumpun.

(4) Berpengaruh sangat nyata (uji $F$ : $F_{\text {hitung }}$ $>\mathrm{F}_{\text {tabel }}$ ) taraf $1 \%$ hasil polong per polybag.

(5) Berpengaruh sangat nyata (uji $\mathrm{F}$ : $\mathrm{F}_{\text {hitung }}$ $\left.>\mathrm{F}_{\text {tabel }}\right)$ taraf $1 \%$ pada jumlah polong per rumpun.

yang sangat nyata terhadap beberapa komponen pertumbuhan dan komponen hasil yang diamati.

\section{KESIMPULAN DAN SARAN}

\section{A. Kesimpulan}

a. Pengaruh perlakuan Pengapuran dolomit terhadap pertumbuhan dan hasil kacang tanah : (1) Berpengaruh sangat nyata (taraf $1 \%$ ) terhadap tinggi tanaman umur 21, 42 dan 63 HST, (2) Tidak berpengaruh nyata pada jumlah cabang per rumpun, (3) Berpengaruh nyata (taraf $5 \%$ ) pada jumlah bunga per rumpun, (4) Berpengaruh sangat nyata (taraf $1 \%$ ) pada hasil polong per polybag, dan (5) Berpengaruh sangat nyata (taraf $1 \%$ ) pada jumlah polong per rumpun.
Dari penjelasan hasil sidik ragam di atas, menunjukkan bahwa interaksi berpengaruh sangat nyata terhadap sejumlah peubah yang diamati baik pertumbuhan maupun hasil kacang tanah. Hal ini disebabkan, pemberian kapur dalam tanah dapat meningkatkan $\mathrm{pH}$ pada tanah-tanah tergenang sehingga keadaan ini dapat berpengaruh terhadap serapan fosfor.di samping itu pemberian kapur juga dapat menambah unsur hara ke dalam tanah terutama $\mathrm{Ca}$, Penyediaan fosfor yang didapatkan dari SP-36 relatif lambat, sedangkan penyediaan unsur hara kalsium (Ca) dan magnesium $(\mathrm{Mg})$ yang berasal dari kapur relatif cepat tersedia sehingga dapat menambah laju pertumbuhan tanaman kacang tanah. Kation $\mathrm{Ca}$ dan $\mathrm{Mg}$ dapat meningkatkan penyerapan ion phosphat dan sebaliknya ion phosphat dari SP-36 dapat memacu penyerapan ion $\mathrm{Ca}$ dan $\mathrm{Mg}$. Keadaan inilah yang mengakibatkan pengaruh interaksi

b. Pengaruh perlakuan pemupukan fosfor terhadap pertumbuhan dan hasil kacang tanah : (1) Berpengaruh sangat nyata (taraf $1 \%$ ) terhadap tinggi tanaman umur 21 dan 42 HST, (2) Tidak berpengaruh nyata pada jumlah cabang per rumpun, (3) Berpengaruh sangat nyata (taraf $1 \%$ ) pada jumlah bunga per rumpun, (4) Berpengaruh sangat nyata (taraf $1 \%$ ) pada hasil polong per polybag, dan (5) Berpengaruh nyata (taraf $5 \%$ ) pada jumlah polong per rumpun.

c. Interaksi antara Pengapuran dolomite dan pemupukan fosfor terhadap pertumbuhan dan hasil kacang tanah pada semua peubah yang diteliti (tinggi tanaman, jumlah cabang per rumpun, jumlah bunga per rumpun, hasil polong per polybag dan jumlah polong per 
rumpun), menunjukkan pengaruh yang sangat nyata (taraf $1 \%)$.

\section{B. Saran-saran}

a. Agar dapat mengoptimalkan hasil pertumbuhan dan produksi kacang tanah, pemberian kapur dolomit dan pupuk fosfor dianjurkan 15 hari sebelum tanam dan dibiarkan selama 1 (satu) minggu.

b. Dalam penelitian ini perlu adanya sosialisasi lebih lanjut dari instansi instansi terkait ke tingkat petani tentang tata cara penggunaan pupuk (dolomit dan fosfor) serta pengelolaan dalam budidaya kacang tanah yang baik dan efisien agar dapat meningkatkan hasil produksi kacang tanah semaksimal mungkin sehingga taraf hidup petani dapat lebih ditingkatkan.

c. Perlu adanya penelitian lanjutan tentang faktor - faktor lain yang terkait, mengingat penelitian ini sangat terbatas karena berkenaan dengan ; musim, jenis tanaman, varietas, lokasi penelitian dari stadium pertumbuhan tanaman.

\section{DAFTAR PUSTAKA}

Anonim, 1982. Dolomit Pupuk Alam Untuk Tanah Asam. PT Polowijo

Mulyani, S. 1997. Pengaruh pemberian fosfor dan effective microorganism 4 (EM.4) terhadap serapan P Bobot Bahan Kering dan Hasil Tanaman Kedelai Makalah pada Seminar Nasional dan Kongress III. Himpunan Gambut Indonesia. Pemda Tingkat UI Kaltim Universitas Tanjung Pura Pontianak.
JAR,Volume 3 Nomor 2 Agustus 2020 $p$-ISSN 2615-417X, $e$-ISSN 2721-0782

Gosari. Sekapuk Sidayu, Gresik. Jawa Timur.

Barber, S. 1984. Soil Nutrient Bio Availability A Mechanistic Approach. John Willey \& Sons. New York. Chichester Briban Toronto Singapore.

Gardner, F.P, R. B, Pearce and R. I, Mitchelk. Fisiologi Tanaman Budidaya (Terjemahan Herawati Susilo) Universitas Indonesia, Jakarta.

Hakim, N. Nyakpa. M.Y, A.M. Lubis. S.G, Nugroho. M. R, Saul. M.A, Diha. G Ban Hong dan H.M. Bailey. 1986. Dasar - Dasar Ilmu Tanah. Universitas Lampung.

Hardjowigeno, S. 1993. Klasifikasi Tanah dan Pedogenesis. Akademi pressindo. Jakarta.

Loveless, A. R. 1989. Prinsip-prinsip Biologi Tumbuhan untuk Daerah Tropik. PT. Gramedia, Jakarta.

Mallarino, A. P. 1995. Evaluation of axcess Soil Phosphorus Supply for Corn by The Ear-leaf Agron. J. 87: 687-691.

Nurhayati Hakim, A. Yusup Nyakpa; A.M. Lubis; S.G. Nugraha; Rusdi Saul; Amin Diha; Go Ban Hong dan H.V. Baily, 1983. Dasar-dasar Ilmu Tanah. Unlam. Lampung.

Sumarno, 1986, Teknik Budidaya Kacang Tanah, Sinar Baru, Bandung.

Suprapto, HS. 2000. Bertanam Kacang Tanah. Penebar swadaya. Jakarta. 
Sutarto, Sri Hutami Supriati. 1987. Pengaruh Pengapuran dan Pemupukan Terhadap Pertumbuhan dan Produksi Kacang Tanah dalam Penelitian Pertanian. Bogor.
JAR, Volume 3 Nomor 2 Agustus 2020 $p$-ISSN 2615-417X, $e$-ISSN 2721-0782

Widjaja-Adhi, I.P.G., 1983. Pengapuran Tanah Masam Untuk Kedelai, dalam Sadikin Somaatmadja; M. Ismunaji; Sumarno; Mahyuddin Syam; S.O. Manurung den Yuswadi. Kedelai. Puslitbangtan. Bogor 